Original Article

\title{
THE EFFECTS OF EXPOSURE DURATION TO ELECTRONIC CIGARETTE SMOKE ON DIFFERENCES IN SUPEROXIDE DISMUTASE AND MALONDIALDEHYDE IN BLOOD OF WISTAR RATS
}

\author{
RIVAN VIRLANDO SURYADINATA ${ }^{1}$, BAMBANG WIRJATMADI², MERRYANA ADRIANI², SRI SUMARMI² \\ ${ }^{1}$ Faculty of Medicine, Universitas Surabaya (UBAYA), Surabaya, ${ }^{2}$ Faculty of Public Health, Airlangga University, Surabaya \\ Email: rivan.virlando.suryadinata@gmail.com
}

Received: 15 Feb 2019, Revised and Accepted: 11 Apr 2019

\begin{abstract}
Objective: Exposure to electronic cigarette smoke causes an increase of free radicals. Physiologically, the body produces antioxidant superoxide dismutase to neutralize the free radicals. However, an excessive increase of the free radicals will result in an imbalance between the amount of free radicals and antioxidants. The free radicals in the body can trigger lipid peroxidation so that it will result in oxidative stress causing cell damage. Malondialdehyde increase is a marker of oxidative stress in the body. The aim of this research is to understand the changes and the relationship between levels of superoxide dismutase and malondialdehyde in the blood due to exposure to electronic cigarette smoke.
\end{abstract}

Methods: This research is an experimental study using male Wistar rats as experimental animal models. In the study, the exposure to electronic cigarette smoke with different duration of administration was carried out. Next, blood samples were taken to check the levels of superoxide dismutase and malondialdehyde.

Results: The results showed a difference in antioxidant levels between antioxidant Superoxide Dismutase and malondialdehyde ( $<<0.05$ ). Meanwhile the relationship between the two groups showed a strong $(r=0.893)$ and significant $(p=0.000)$ relationship.

Conclusion: The exposure to electronic cigarette smoke can reduce the level of antioxidant superoxide dismutase and increase the level of malondialdehyde in blood. In addition, changes in the levels of antioxidant superoxide dismutase and malondialdehyde had a strong and significant relationship.

Keywords: Superoxide Dismutase, E-Cigarette, Malondialdehyde, Free Radical

(C) 2019 The Authors. Published by Innovare Academic Sciences Pvt Ltd. This is an open-access article under the CC BY license (http://creativecommons.org/licenses/by/4.0/) DOI: http://dx.doi.org/10.22159/ijcpr.2019v11i3.34084

\section{INTRODUCTION}

Electronic cigarettes have become one of the alternative products as a substitute for tobacco cigarettes. Electronic cigarettes are claimed by most people to be safer than the tobacco cigarettes. Furthermore, intense promotion has increasingly accelerated the use of electronic cigarettes in public [1]. In 2016, the use of electronic cigarettes in America had reached $4.3 \%$ among middle school children and $11.3 \%$ among high school children [2]. Besides, one-third of teenagers in America consider electronic cigarettes to be less dangerous than the tobacco cigarettes [3]. The usage prevalence of electronic cigarettes in several countries in Asia is smaller, such as in China (3.1\%), in Taiwan (3\%), and in Hong Kong $(2.3 \%)$. This is due to the less aggressive promotion of electronic cigarettes compared to the one in the Western countries [4].

Various studies have shown the dangers posed by the exposure to cigarette smoke. The electronic cigarettes contain harmful substances just as the ones in the tobacco cigarettes [5]. The exposure to electronic cigarette smoke entering the airways can be dangerous for lung tissues [6]. It will trigger an increase of free radicals in the body. These free radicals bind to oxygen and form Reactive Oxygen Species (ROS) [7]. One type of Reactive Oxygen Species (ROS) that is harmful to the body is superoxide radical $(02 \bullet)$. The free radical can be neutralized through an enzymatic antioxidant, namely Superoxide Dismutase. Moreover, Superoxide Dismutase can also serve as an anti-inflammatory and prevent pre-cancerous cell changes[8]. Unfortunately, an increase in excessive free radicals in the body will cause a disruption of the balance between the amounts of antioxidants in the body, so that it can lead to oxidative stress. This reaction will cause lipid peroxidation, resulting in cell damage [9]. The result of lipid peroxidation is malondialdehyde which is often used as a parameter to measure the increase of free radicals in the body [10].

Reactive Oxygen Species (ROS) does not only have negative impacts on the body, because the production of Reactive Oxygen Species
(ROS) at the physiological level will function to fight pathogen invasion and induce immune responses against the effects of pathogens; but also positive impacts since it increases cellular activities, induces enzymes, maintains chemical balance and controls hormone levels. Thus, the amount of free radicals in the body should not be either too high or too low [11].

The exposure to electronic cigarette smoke has bad impacts on airways. Even a 5-minute exposure to electronic cigarette smoke can already cause airway disorders [12]. Moreover, an increase in free radicals due to the exposure to electronic cigarette smoke can also lead to various diseases such as Chronic Obstructive Pulmonary Disease (COPD), Asthma and various types of respiratory disorders $[13,14]$. Therefore, this study will observe the effect of giving exposure to electronic cigarette smoke on the levels of antioxidant superoxide dismutase and malondialdehyde in blood with different time periods. Hence, this study can describe the harmful effects of free radicals of electronic cigarette smoke.

\section{MATERIALS AND METHODS}

This research is an experimental study using a post-test control group design. The study was conducted for $4 \mathrm{w}$ in 1 February 201911 March 2019 and the intervention time was adjusted. The research sample was male Wistar rats (Rattus novergicus). The study was divided into 6 groups with different time exposure to electronic cigarrete smoke for each group. The provided exposure to electronic cigarrete was done for 5 min each time the intervention was given. What made the difference for each group was the administration and the duration every week.

Rats

Male Wistar rats aged 2-3 mo weighing 150-200 grams were used as experimental animal models. Macroscopically, there were no abnormalities found. The rats were also never been subjects of any 
research. Before administering the intervention, the experimental animal models were the first subject to laboratory adaptation for 5 d. The research was conducted in the Laboratory of the Faculty of Medicine, Universitas Airlangga. Each group was given the same amount of exposure period, but the selenium administration was done in different times.

\section{Sample size}

The calculation of the replication sample size was used to compare the treatment groups.

$$
\mathrm{n}=\left\{\frac{\left(\mathrm{Z}_{1-\alpha}+\mathrm{Z}_{1-\beta}\right) \cdot \sigma}{\mu_{1}-\mu_{0}}\right\}^{2}
$$

The result of minimum sample calculation used in this study was 5 male Wistar rats in each group.

\section{E-cigarette}

The used solution of electronic cigarettes contained $6 \mathrm{mg}$ of nicotine. The room of exposure to electronic cigarette smoke was $50 \mathrm{~cm}$ x 40 $\mathrm{cm} \times 20 \mathrm{~cm}$ in size. The room was passed by a pipe draining electronic cigarette smoke. The exposure administration to cigarette smoke was adjusted for the administration duration as planned in this study.

\section{Measurement of superoxide dismutase level in the blood}

The measurement of Superoxide Dismutase level in blood was carried out using an Enzyme-Linked Immuno sorbent Assay (ELISA) Kit which can be applied in the quantitative in vitro determination of Rat SOD1 concentration in serum, plasma and other biological fluids. The ELISA kit uses the Competitive-ELISA method. The kit had been coated with Rat SOD1 as a specific antibody. Color changes were measured by spectrophotometry at a wavelength of $450 \mathrm{~nm} \pm 2 \mathrm{~nm}$. The Rat SOD 1 concentration in the sample was then determined by comparing the sample OD to the standard curve.

\section{Measurement of malondialdehyde level in the blood}

The measurement of malondialdehyde level in blood was carried out using Thiobarbituric Acid Reactive Substance (TBARS) Assay. The test was directly and accurately carried out to detect using the Bioassay System based on the reaction of TBARS with Thiobarbituric Acid (TBA) in forming a pink product or compound. The color intensity was measured at $535 \mathrm{~nm}$ or with fluorescence intensity at $560 \mathrm{~nm} / 585 \mathrm{~nm}$ which was directly proportional to the concentration of TBARS in the sample.

\section{Research implementation}

The first group was the negative control group where the experimental animal models were not given any intervention for 4 w. The second group was the treatment group I where the experimental animal models were intervened by exposure to electronic cigarette smoke once for $5 \mathrm{~min}$ per day for $1 \mathrm{w}$. The third group was the treatment group II where the experimental animal models were given intervention in exposure to electronic cigarette smoke twice for 5 min per day for $1 \mathrm{w}$. The fourth group was the treatment group III where the experimental animal models were intervened by exposure to electronic cigarette smoke 1 time $5 \mathrm{~min}$ per day for $2 \mathrm{w}$. The fifth group was the IV treatment group where the experimental animal models were given intervention in exposure to electronic cigarette smoke twice for $5 \mathrm{~min}$ per day for 2 w. The sixth group was the treatment group $\mathrm{V}$ where the experimental animal models were intervened by exposure to electronic cigarette smoke once for 5 min per day for $3 \mathrm{w}$.

\section{Statistics}

The collected data underwent statistical testing using ANOVA analysis with SPSS version 20 to see differences in the levels of superoxide dismutase and malondialdehyde in the blood of all groups. Next, the Least Significant Difference (LSD) test was conducted to compare between the groups. In addition, a correlation test was performed to understand the relationship between the two groups.

\section{RESULTS}

The results of the study were obtained by comparing the levels of superoxide dismutase and malondialdehyde in each group. Based on table 1, the mean values and differences in Superoxide Dismutase level in each group can be seen. These results showed a decrease in antioxidant level in each group which was inversely proportional to the time duration of exposure administration to the electronic cigarette smoke. In the group, I, the antioxidant Superoxide Dismutase value reached $5.64 \pm 0.12$, which was the highest average value in all groups. Meanwhile, the lowest mean value was obtained in group VI reaching $0.87 \pm 0.05$.

Table 1: The mean value and ANOVA test for superoxide dismutase (SOD) in each group

\begin{tabular}{llll}
\hline & Groups & mean \pm SD & P Value \\
\hline I & Control Group & $5,64 \pm 0,12$ \\
II & Treatment Group I & $4,35 \pm 0,07$ \\
III & Treatment Group II & $2,92 \pm 0,08$ \\
IV & Treatment Group III & $2,3 \pm 0,06$ \\
V & Treatment Group IV & $1,49 \pm 0,07$ \\
VI & Treatment Group V & $0,87 \pm 0,05$ \\
\hline
\end{tabular}

The results of ANOVA analysis on Superoxide Dismutase level showed differences in Superoxide Dismutase level in various groups $(p=0,000)$. It was then analyzed using the Least Significant Difference (LSD) test to see differences in Superoxide Dismutase level between the groups (table 2). Based on table 2, there are significant differences $(\mathrm{p}<0.005)$ in Superoxide Dismutase level between the negative control group and all of the treatment groups.

Table 2: Least significant difference (LSD) test results on superoxide dismutase (SOD) levels in each group

\begin{tabular}{lllllll}
\hline Groups & I & II & III & IV & V & VI \\
\hline I & - & - & - & - & - & - \\
II & 0,000 & - & - & - & - & - \\
III & 0,000 & 0,000 & - & - & - & - \\
IV & 0,000 & 0,000 & 0,000 & 0,000 & - & - \\
V & 0,000 & 0,000 & 0,000 & 0,000 & 0,000 & - \\
VI & 0,000 & 0,000 & 0,000 & - \\
\hline
\end{tabular}

Based on table 3, it was shown that the average value of the malondialdehyde level was directly proportional to the duration of exposure to cigarette smoke. In group I, the malondialdehyde level reached the lowest value of $0.0144 \pm 0.0008$, while the highest value was found in group VI which was $0.1444 \pm 0.0037$. 
Table 3: The mean value and ANOVA test for malondialdehyde (MDA) in each group

\begin{tabular}{lll}
\hline & Groups & mean \pm SD \\
\hline I & Control Group & $0,0144 \pm 0,0008$ \\
II & Treatment Group I & $0,0282 \pm 0,0013$ \\
III & Treatment Group II & $0,0412 \pm 0,0020$ \\
IV & Treatment Group III & $0,0590 \pm 0,0037$ \\
V & Treatment Group IV & $0,0942 \pm 0,0040$ \\
VI & Treatment Group V & $0,1444 \pm 0,0037$ \\
\hline
\end{tabular}

The ANOVA analysis of malondialdehyde level showed differences in malondialdehyde level in various groups $(\mathrm{p}=$ $0,000)$. Next, it was analyzed using the Least Significant Difference (LSD) test to see differences in malondialdehyde level between the groups (table 4). Based on table 4, there were significant differences $(\mathrm{p}<0.005)$ in the malondialdehyde level between the negative control group and all of the treatment groups.

Table 4: Least significant difference (LSD) test results on malondialdehyde (MDA) levels in each group

\begin{tabular}{llllll}
\hline Groups & I & II & III & IV & VI \\
\hline I & - & - & - & - & - \\
II & 0,002 & - & - & - & - \\
III & 0,000 & 0,003 & - & - & - \\
IV & 0,000 & 0,000 & 0,000 & 0,000 & - \\
V & 0,000 & 0,000 & 0,000 & - & - \\
VI & 0,000 & 0,000 & 0,000 & 0,000 & 0,000 \\
\hline
\end{tabular}

The results of the correlation test analysis showed that there was a strong correlation between Superoxide Dismutase level and Malondialdehyde Level $(r=0.893)$. In addition, the two groups had a significant relationship $(p<0.05)$ (table 5).

Table 5: Test results correlation between superoxide dismutase levels and malondialdehyde levels between groups

\begin{tabular}{lll}
\hline Variable & Correlation value & P value \\
\hline $\begin{array}{l}\text { Superoxide Dismutase Level } \\
\text { Levels of malondialdehyde }\end{array}$ & 0,893 \\
\hline
\end{tabular}

\section{DISCUSSION}

The exposure to electronic cigarette smoke entering the airways will reduce the level of antioxidant superoxide dismutase and increase the level of malondialdehyde in blood. This is because the exposure to electronic cigarette smoke contains various kinds of hazardous chemicals having impacts on an increase of free radicals in the airways [15]. Superoxide radicals entering the airways will be directly neutralized by the antioxidant superoxide dismutase [10]. However, the excessive increase of superoxide radicals will cause a decrease in the body's antioxidant levels. Furthermore, an increase in malondialdehyde level also shows an increase in lipid peroxidation triggered by an increase in free radicals which is imbalanced of an increase in antioxidant level in the blood [16].

The free radicals that are still reactive will directly react with cell membranes. This will cause damage to cells in the airways and increase the inflammatory reaction. This process will impact on the existence of airway obstruction so that it can trigger acute exacerbations [17, 18]. Antioxidant enhancement can be done through food intake as a means to increase exogenous antioxidant levels. The recommended sources of vitamins for antioxidant enhancement are Vitamin A, C, D, and E in the food or supplement forms. This can affect the reduction of free radicals, so that cell damage can be prevented $[19,20]$.

This research shows that the electronic cigarette can increase the free radicals in blood just like the tobacco cigarette does. Moreover, it also decreases the level of superoxide dismutase. Thus, it can be stated that electronic cigarettes will have bad impacts on health [21,22].

\section{CONCLUSION}

The exposure to electronic cigarette smoke can reduce the level of antioxidant superoxide dismutase and increase the level of malondialdehyde in blood. In addition, changes in the levels of antioxidant superoxide dismutase and malondialdehyde had a strong and significant relationship.

\section{ACKNOWLEDGMENT}

Thank you for the Promoter and Co-promoters who have guided and provided advice for my research and teaching staff in the Doctoral Program of public health, Faculty of Public Health, Airlangga University, Surabaya.

\section{AUTHORS CONTRIBUTIONS}

All the author have contributed equally

\section{CONFLICT OF INTERESTS}

\section{Declare none}

\section{REFERENCES}

1. EP Perikleous, P Steiropoulos, E Paraskakis, TC Constantinidis, E Nena. E-cigarette use among adolescents: an overview of the literature and future perspectives. Front Public Heal 2018;6:86.

2. A Jamal. Tobacco use among middle and high school in the students-United States, 2011-2016. MMWR Morb Mortal Wkly Rep 2017;66:597-603.

3. BK Ambrose. Perceptions of the relative harm of cigarettes and e-cigarettes among U. S. Youth. Am J Prev Med 2014;47:S53S60.

4. Y Cheung. Public support for electronic cigarette regulation in hong kong: a population-based cross-sectional study. Int J Environ Res Public Health 2017;14:709.

5. CA Lerner. Vapors produced by electronic cigarettes and ejuices with flavorings induce toxicity, oxidative stress, and inflammatory response in lung epithelial cells and in mouse lung. PLoS One 2015;10:e0116732.

6. B Reidel. E-cigarette use causes a unique innate immune response in the lung, involving increased neutrophilic activation and altered mucin secretion. Am J Respir Crit Care Med 2018;197:492-501.

7. RV Suryadinata, B Wirjatmadi, M Adriani. Pengaruh perubahan hiperplasia sel goblet selama 28 hari paparan asap rokok 
dengan pemberian antioksidan superoxide dismutase. Indones J Public Heal 2017;11:60.

8. H Younus. Therapeutic potentials of superoxide dismutase. Int J Health Sci (Qassim) 2018;12:88-93.

9. R Virlando Suryadinata. Pengaruh radikal bebas terhadap proses inflamasi pada penyakit paru obstruktif kronis (PPOK) effect of free radicals on the inflammatory process in chronic obstructive pulmonary disease (COPD). Am Nutr 2018;2:317-24.

10. RV Suryadinata, B Wirjatmadi, M Adriani. Efektivitas penurunan malondialdehyde dengan kombinasi suplemen antioksidan superoxide dismutase melon dan gliadin akibat paparan rokok. Glob Med Helath Commun 2017;5:79-83.

11. N Panth, KR Paudel, K Parajuli. Reactive oxygen species: a key hallmark of cardiovascular disease. Adv Med 2016:1-12. http://dx.doi.org/10.1155/2016/9152732.

12. CI Vardavas, N Anagnostopoulos, M Kougias, V Evangelopoulou, GN Connolly, PK Behrakis. Short-term pulmonary effects of using an electronic cigarette. Chest 2012;141:1400-6.

13. Global Initiative for Chronic Obstructive. 2018 global strategy for prevention, diagnosis and management of COPD. Glob Obstr Lung Dis 2018. Available from: http://www.goldcopd.org. [Last accessed on 10 Jan 2019].

14. PII Indraswari, A Lorensia, RV Suryadinata. Analysis effect of nutrition intake on lung function of an active smoker and nonsmoker. J Kesehat Masy 2018;14:247-53.
15. G Kamceva, $\mathrm{Z}$ Arsova Sarafinovska, $\mathrm{T}$ Ruskovska, M Zdravkovska, L Kamceva-Panova, E Stikova. Cigarette smoking and oxidative stress in patients with coronary artery disease. Open Access Maced J Med Sci 2016;4:636.

16. IA Groner. Oxidative stress in youth and adolescents with elevated body mass index exposed to secondhand smoke. Nicotine Tob Res 2016;18:1622-7.

17. Y Li. Cigarette smoke-induced pulmonary inflammation and autophagy are attenuated in Ephx2-deficient mice. Inflammation 2017;40:497-510.

18. R Anderson, PWA Meyer, MMTM Ally, M Tikly. Smoking and air pollution as pro-inflammatory triggers for the development of rheumatoid arthritis. Nicotine Tob Res 2016;18:1556-65.

19. SR Pratiwi, A Lorensia, RV Suryadinata. Asupan vitamin c dan e dengan SQ-FFQ terhadap fungsi paru perokok dan nonperokok. Media Kesehat Masy Indones 2018;14:101.

20. RV Suryadinata, B Wirjatmadi, M Adriani, S Sumarmi. Effects of knowledge of vitamin D on attitudes toward sun exposure among middle-aged and elderly Indonesian adults. Indian J Public Heal Res Dev 2018;9:1692-6.

21. M Hua, $P$ Talbot. Potential health effects of electronic cigarettes: a systematic review of case reports. Prev Med Reports 2016;4:169-78.

22. BA Majeed. Changing perceptions of harm of e-cigarettes among U. S. Adults, 2012-2015. Am J Prev Med 2017;52:331-8. 